J. Lake Sci. (湖泊科学) , 2010, 22(1): 44-48

http: //www.jlakes.org. E-mail: jlakes@niglas.ac.cn

(c) 2010 by Journal of Lake Sciences

\title{
南京玄武湖蓝藻水华治理后水质和浮游植物的动态变化
}

\author{
梅卓华, 张哲海, 赵春霞, 徐 敏, 李 敏 \\ (南京市环境监测中心站,南京 210013)
}

摘 要: 玄武湖是典型的城市富营养化湖泊,2005 年夏季暴发了大面积微囊藻水华, 其后以粘土法为主, 对微囊藻水华进 行了应急治理. 为了解应急治理后玄武湖水生态状况的变化, 通过分析治理后浮游植物种类和数量变化以及重要理化指 标的变化, 探讨应急治理对湖水水质和浮游植物群落的影响. 通过对比治理前和水华暴发期的监测数据, 发现治理后浮 游植物数量减少, 种类增多; 湖水总磷和叶绿素 $\mathrm{a}$ 的浓度都明显降低; 水体透明度大幅提高, 湖水总氮浓度随浮游植物的 密度和菹草的生长而出现波动.

关键词: 治理;水质;浮游植物;玄武湖

\section{Dynamics of phytoplankton and water quality with control of cyanobacterial bloom in Lake Xuanwu, Nanjing}

MEI Zhuohua, ZHANG Zhehai, ZHAO Chunxia, XU Min \& LI Min

(Nanjing Environmental Monitoring Central Station, Nanjing 210013, P. R. China)

Abstract: Lake Xuanwu is a typical urban eutrophic lake. Microcystis bloom broke out in a large area of Lake Xuanwu in the summer of 2005. The main method used to control the Microcystis bloom was the application of modified clay. In order to discover the changes of the water ecological situation, the following tests were performed: inquiry into the changes of the quality of water and phytoplankton after the treatment, the analysis to the type and quantity of phytoplankton and physico-chemical indexes . The results show: the amount of phytoplankton reduced, while the species increased after the treatment, the concentration of Chl. a and TP reduced, with a substantial increase in SD, the concentration of TN was undulatory with phytoplankton density and Potamogeton crispus growth.

Keywords: Treatment; water quality ; phytoplankton; Lake Xuanwu

玄武湖面积 $3.7 \mathrm{~km}^{2}$, 平均水深 $1.14 \mathrm{~m}$, 最大水深为 $2.31 \mathrm{~m}$, 库容约 $5 \times 10^{6} \mathrm{~m}^{3}$. 早在 20 世纪 80 年代后期, 玄武湖湖水已经处于严重的富营养化状态 ${ }^{[1]}$. 自 20 世纪 90 年代初起,采取了截污、清淤、引水冲污等措施, 以控制玄武湖富营养化、改善水质,然而,2005 年夏季,玄武湖首次发生大面积以微囊藻 (Microcystis sp.) 为 主要优势种群的蓝藻水华, 局部区域散发恶臭气味, 严重影响了湖水的景观、养殖和水上运动功能. 为了尽 快控制蓝藻水华, 保障玄武湖各种环境功能, 当地政府采取了粘土絮凝、菌制剂杀藻等措施, 对玄武湖蓝藻 水华进行了应急治理,共使用改性粘土约 300t, 湖面喷酒粘土达 $106.0 \mathrm{~g} / \mathrm{m}^{2} .10$ 月底, “藻华”现象基本消失. 在蓝藻暴发和治理过程中玄武湖高等水生植物没有明显变化,但 2005 年 11 月至 2006 年 4 月, 玄武湖各湖 区出现了的大量菹草生长,期间采用机械和人工打捞来除草.

通过对浮游植物种类和数量以及重要理化指标的监测, 探讨应急治理对湖水水质和浮游植物群落的影 响,给玄武湖的科学治理和管理提供基础资料.

\section{1 调查研究方法}

在玄武湖湖面设置 4 个监测点 (图 1), 于 2006 年 4 月至 2007 年 3 月对该湖逐月监测, 监测项目包括浮

* 南京市环境保护局项目 (200610) 资助. 2008-12-02 收稿;2009-09-14 收修改稿. 梅卓华,女,1970 年生, 高级工 程师;E-mail:meizhuoh@ sina. com. 
游植物、叶绿素 $\mathrm{a} 、$ 总磷、总氮、高锰酸盐指数、透明度、 水温. 浮游植物、叶绿素 $\mathrm{a} 、$ 总磷、总氮、高镇酸盐指数均 采集水面以下 $50 \mathrm{~cm}$ 的水样, 监测方法依据《水和废水 监测分析方法》(第四版); 透明度 $(\mathrm{SD})$ 由塞氏盘测定; 水温用美国 YSI - 58 型溶解氧仪于水下 $20 \mathrm{~cm}$ 测定.

2006 年 4 月之前的数据来源于南京市环境监测中 心站的年度统计资料. 运用 SPSS13.0 分析统计软件分 析数据相关性.

\section{2 结果和分析}

\section{1 浮游植物种类组成}

大规模治理蓝藻水华之后的一年中 (2006 年 4 月2007 年 3 月), 玄武湖各湖区共监测到浮游植物 7 门 82 属 176 种, 其中绿藻门 39 属 89 种占种数的 $50.6 \%$, 硅 藻门 20 属 35 种占种数的 $19.9 \%$, 蓝藻门 12 属 19 种占 种数的 $10.8 \%$, 裸藻门 4 属 20 种占种数的 $11.4 \%$, 隐

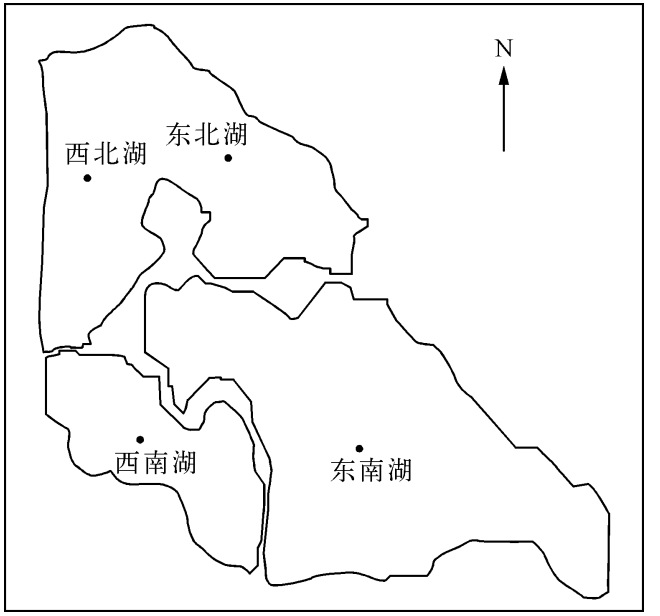

图 1 玄武湖监测点位示意图

Fig. 1 Sketch of sampling sites in Lake Xuanwu 藻门 2 属 6 种占种数的 $3.4 \%$, 甲藻门 3 属 4 种占种数的 $2.3 \%$, 金藻门 1 属 2 种占种数的 $1.1 \%$, 黄藻门 1 属 1 种占种数的 $0.6 \%$.

\section{2 浮游植物的数量与季节变化}

水体中浮游植物的种类、数量及分布情况是水质状况的标志之一. 水体营养盐浓度、水温条件和光照强 度与藻类细胞密度变化密切相关. 治理后的一年中, 玄武湖的藻类细胞密度在 $6.93 \times 10^{6}-2.28 \times 10^{8} \mathrm{cells} / \mathrm{L}$ 之间波动, 年均细胞密度为 $5.32 \times 10^{7} \mathrm{cell} / \mathrm{s} / \mathrm{L}$. 玄武湖藻类细胞密度的最高值出现在夏季 $7 、 8$ 月, 数量级在 $10^{8} \mathrm{cells} / \mathrm{L}$; 而春季 $3 、 4$ 月份最低, 数量级在 $10^{6} \mathrm{cells} / \mathrm{L} ; 6$ 月份是藻类密度快速上升时期, 9 月则是藻类密度 快速下降时期,秋、冬季藻类密度维持在 $10^{7}$ cells $/ \mathrm{L}$ (图 2a).

从优势种变化看, 玄武湖的优势种主要为蓝藻和硅藻, 4-5 月以小环藻 (Cyclotella sp. ) 为优势种, 5-6 月以席藻 (Phormidium sp.) 为优势种, 7-8 月以微囊藻 (Microcystis sp.) 为优势种, 9 月至翌年 3 月以银灰平 裂藻 (Merismopedia glauca) 为优势种. 蓝藻门的微囊藻、席藻都属于富营养藻类. 硅藻门的小环藻和蓝藻门的 平裂藻则属于中营养藻类. 随着季节的变化, 上述种类在玄武湖交替出现, 成为优势种, 反映了玄武湖富营 养化的程度和季节变化.

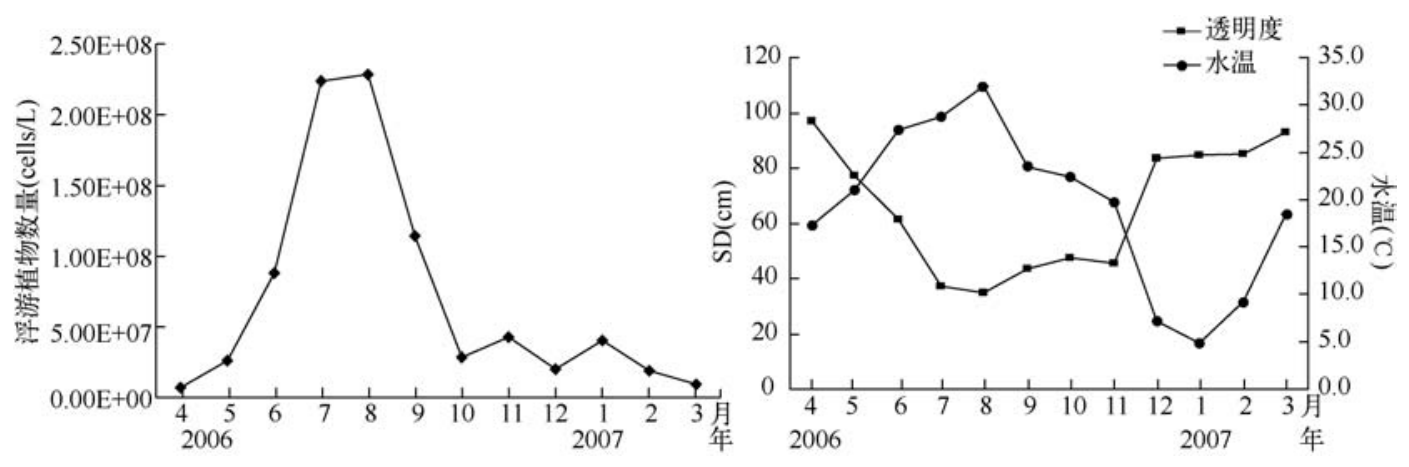

图 2 玄武湖浮游植物数量 $(\mathrm{a})$ 和水温、透明度 $(\mathrm{b})$ 变化

Fig. 2 Dynamics of quantity of phytoplankton(a) and water temperature, SD(b) in Lake Xuanwu

\section{3 玄武湖水质及动态}

2006 年 4 月 -2007 年 3 月期间温度和透明度 (SD) 的变化情况显示 (图 2b), 随着水温的升高, SD 明显 降低, 8 月水温最高, $\mathrm{SD}$ 最低; 当水温降低, $\mathrm{SD}$ 就明显升高, 从 12 月至翌年 4 月,玄武湖的 $\mathrm{SD}$ 为全年最高, 
清澈见底, 这与菹草吸收水体和沉积物中的营养盐、减少沉积物及其中的营养盐再悬浮释放, 改善水体透明 度及水质有密切关系.

玄武湖 TN 浓度一直保持在较高水平, 全年平均为 $1.69 \mathrm{mg} / \mathrm{L}$ (表 1 ), 在水温较低的 12 月、1 月和 2 月 $\mathrm{TN}$ 浓度有所升高. $\mathrm{NO}_{3}-\mathrm{N}$ 和 $\mathrm{NO}_{2}-\mathrm{N}$ 的变化趋势与 $\mathrm{TN}$ 较为一致. 有研究表明 ${ }^{[2-3]}$, 当水中 $\mathrm{NH}_{3}-\mathrm{N}$ 浓度较低 $(<0.35 \mathrm{mg} / \mathrm{L})$ 时, 菹草优先吸收 $\mathrm{NO}_{3}-\mathrm{N}$. 玄武湖淔草的大量繁殖抑制了浮游植物的生长, 所以水中的 Chl. a 浓度相应降低. 经相关性分析显示 $\mathrm{NO}_{3}-\mathrm{N}$ 的浓度与 Chl. a 的浓度有显著负相关性 (相关系数为 -0.863 ).

$\mathrm{TP}$ 的浓度范围为 $0.04-0.33 \mathrm{mg} / \mathrm{L}$, 最低浓度出现在 4 月, 最高浓度在 9 月 (表 1); $\mathrm{PO}_{4}-\mathrm{P}$ 的浓度变化与 微囊藻的繁殖相关, 当 $\mathrm{PO}_{4}-\mathrm{P}$ 浓度大于 $0.01 \mathrm{mg} / \mathrm{L}$ 时, 适于微囊藻生长 ${ }^{[4-5]}$, 由于玄武湖的 $\mathrm{TP}$ 浓度都大于等 于 $0.01 \mathrm{mg} / \mathrm{L}$, 所以 $\mathrm{PO}_{4}-\mathrm{P}$ 浓度的变化与微囊藻的生长没有密切的相关性 (相关系数为 0.169 ).

表 1 玄武湖营养盐及叶绿素动态

Tab. 1 Nutrient and Chl. a concentrations in Lake Xuanwu in 2006 and 2007

\begin{tabular}{llllllll}
\hline 时间(年-月 $)$ & $\begin{array}{c}\mathrm{NO}_{2}-\mathrm{N} \\
(\mathrm{mg} / \mathrm{L})\end{array}$ & $\begin{array}{c}\mathrm{NO}_{3}-\mathrm{N} \\
(\mathrm{mg} / \mathrm{L})\end{array}$ & $\begin{array}{c}\mathrm{NH}_{4}-\mathrm{N} \\
(\mathrm{mg} / \mathrm{L})\end{array}$ & $\begin{array}{c}\mathrm{TN} \\
(\mathrm{mg} / \mathrm{L})\end{array}$ & $\begin{array}{c}\mathrm{PO}_{4}-\mathrm{P} \\
(\mathrm{mg} / \mathrm{L})\end{array}$ & $\begin{array}{c}\mathrm{TP} \\
(\mathrm{mg} / \mathrm{L})\end{array}$ & $\begin{array}{c}\mathrm{Chl} . \mathrm{a} \\
(\mu \mathrm{g} / \mathrm{L})\end{array}$ \\
\hline $2006-04$ & 0.01 & 1.39 & 0.06 & 1.64 & 0.02 & 0.06 & 6.13 \\
$2006-05$ & 0.03 & 0.55 & 0.13 & 1.43 & 0.05 & 0.09 & 26.44 \\
$2006-06$ & 0.02 & 0.21 & 0.09 & 1.40 & 0.05 & 0.12 & 71.88 \\
$2006-07$ & 0.02 & 0.09 & 0.18 & 1.34 & 0.06 & 0.18 & 92.70 \\
$2006-08$ & 0.04 & 0.26 & 0.27 & 1.70 & 0.03 & 0.15 & 120.80 \\
$2006-09$ & 0.03 & 0.77 & 0.10 & 1.59 & 0.01 & 0.33 & 55.46 \\
$2006-10$ & 0.03 & 0.89 & 0.09 & 1.59 & 0.01 & 0.06 & 42.64 \\
$2006-11$ & 0.04 & 1.05 & 0.08 & 1.95 & 0.04 & 0.07 & 35.14 \\
$2006-12$ & 0.05 & 1.22 & 0.55 & 2.60 & 0.02 & 0.05 & 21.00 \\
$2007-01$ & 0.04 & 1.46 & 0.19 & 2.12 & 0.01 & 0.05 & 12.00 \\
$2007-02$ & 0.04 & 1.28 & 0.21 & 2.88 & 0.01 & 0.05 & 18.57 \\
$2007-03$ & 0.03 & 0.90 & 0.18 & 1.58 & 0.01 & 0.04 & 22.43 \\
\hline
\end{tabular}

2.4 玄武湖富营养化评价

采用卡尔森综合营养状态指数进行富营养化评价, 计算公式如下:

$$
T L I(\Sigma)=\sum_{j=1}^{m} W_{j} T L I(j)
$$

表 2 水质类别与评分值对应

Tab. 2 Water types and the corresponding score value

\begin{tabular}{ccc}
\hline 营养状态分级 & 评分值 $T L I\left(\sum\right)$ & 定性评价 \\
\hline 贫营养 & $0<T L I\left(\sum\right) \leqslant 30$ & 优 \\
中营养 & $30<T L I\left(\sum\right) \leqslant 50$ & 良好 \\
(轻度) 富营养 & $50<T L I\left(\sum\right) \leqslant 60$ & 轻度污染 \\
(中度) 富营养 & $60<T L I(\Sigma) \leqslant 70$ & 中度污染 \\
(重度) 富营养 & $70<T L I(\Sigma) \leqslant 100$ & 重度污染 \\
\hline
\end{tabular}

式中: $T L I\left(\sum\right)$ 为综合营养状态指数; $W_{j}$ 为第 $j$ 种参 数的营养状态指数的相关权重; $T L I(j)$ 代表第 $j$ 种 参数的营养状态指数.

湖泊水库营养状态分级: 采用 $0-100$ 的一系 列连续数字对湖泊营养状态进行分级 (表 2).

根据 TLI 指数评价玄武湖富营养化状态 ( 表 $3), 1$ 月、 3 月和 4 月玄武湖处于中营养状态; 2 月、 5 月、6 月、 10 月、 11 月和 12 月处于轻度富营养状

态; 7 月、 8 月和 9 月处于中度富营养状态; 全年平均 $T L I$ 为 55.61 , 处于轻度富营养状态.

表 3 玄武湖富营养状态评价

Tab. 3 Assessment of eutrophic status in Lake Xuanwu

\begin{tabular}{|c|c|c|c|c|c|c|c|c|c|c|c|c|}
\hline 日期 & $2006-04$ & $2006-05$ & $2006-06$ & $2006-07$ & $2006-08$ & $2006-09$ & $2006-10$ & $2006-11$ & $2006-12$ & $2007-01$ & $2007-02$ & $2007-03$ \\
\hline$T L I$ & 45.06 & 53.00 & 58.72 & 62.11 & 63.10 & 60.53 & 53.70 & 54.77 & 50.60 & 48.70 & 50.68 & 49.02 \\
\hline 营养 & 中俈差 & (轻度) & (轻度) & (中度) & (中度) & (中度) & (轻度) & (轻度) & (轻度) & 中夢 & (轻度) & 中节差 \\
\hline 状态 & 中宫乔 & 富营养 & 富营养 & 富营养 & 富营养 & 富营养 & 富营养 & 富营养 & 富营养 & 中宫乔 & 富营养 & 中营养 \\
\hline
\end{tabular}




\section{3 讨论}

\section{1 治理前后浮游植物群落特征比较}

2004 年, 玄武湖浮游植物组成主要以蓝藻、绿藻和硅藻为主, 优势种为蓝纤维藻、栅藻和小环藻等. 浮游 植物数量为 $7.9 \times 10^{7}$ cells $/ \mathrm{L} .2005$ 年 6 月, 浮游植物的数量为 $1.68 \times 10^{7} \mathrm{cells} / \mathrm{L}$, 优势种为蓝纤维藻、小环藻 和隐藻, 浮游植物组成与往年基本一致. 7 月蓝藻水华暴发后, 其组成主要以微囊藻为主, 浮游植物数量大幅 上升, 年均数量为 $1.36 \times 10^{8} \mathrm{cells} / \mathrm{L}$, 最高达 $5.23 \times 10^{9} \mathrm{cells} / \mathrm{L} .2006$ 年浮游植物优势种主要为微囊藻、席藻、 银灰平裂藻和小环藻, 最高数量较 2005 年下降一个数量级, 年均数量为 $9.46 \times 10^{7} \mathrm{cells} / \mathrm{L}$. 治理后, 浮游植物 种类也大幅增加, 由 2005 年的 103 种增加到 2006 年的 176 种. 新增种类主要是绿藻门和硅藻门, 还出现了 金藻门的锥囊藻 (图 3a). 从浮游植物数量组成上看, 2006 年仍是蓝藻占绝对优势, 但比例较 2005 年有所下 降, 绿藻、硅藻和裸藻数量有所增加 ( 图 3b).
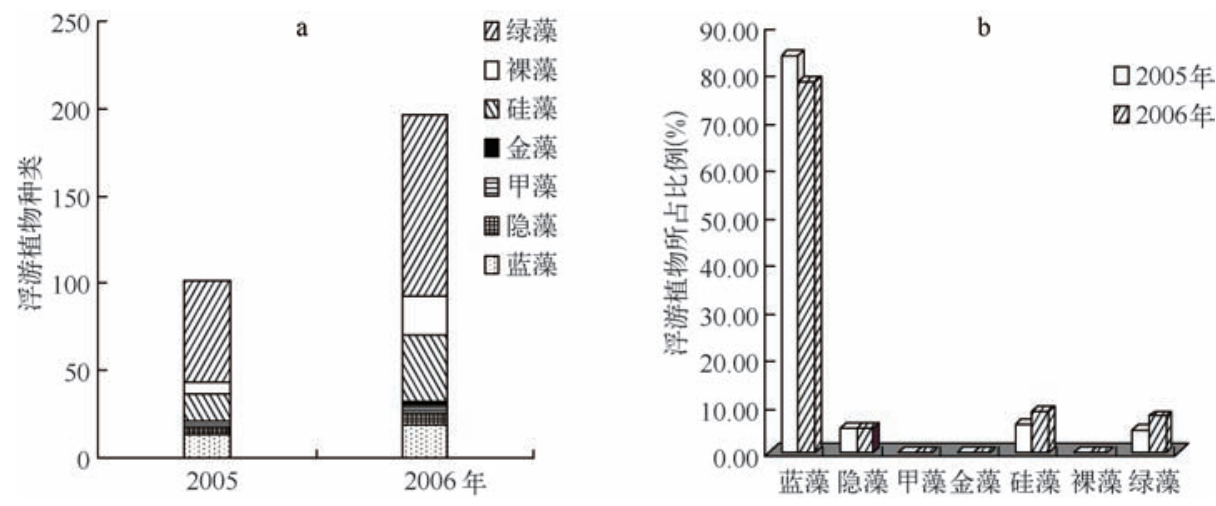

图 32005 年与 2006 年浮游植物种类 (a) 和所占比例 ( b) 变化

Fig. 3 Dynamics of species(a) and composition(b) of phytoplankton in 2005 and 2006

\section{2 治理前后水质的动态变化}

治理前, 玄武湖的透明度一直在 $15-43 \mathrm{~cm}$ 之间, 蓝藻水华暴发期也处于该水平. 治理后, 水体中大量营 养盐随蓝藻沉降到湖泊水土界面, 2005 年 11 月后, 透明度大幅提高. 2006 年 1 月达到历史最高点, 玄武湖水 体清澈见底,2006 年全年透明度都高于治理前同期水平 (图 4a).

治理前, 玄武湖的 TN 浓度一直保持在较高水平, 在 $1.15-1.98 \mathrm{mg} / \mathrm{L}$ 之间 (图 4b), 均值为 $1.51 \mathrm{mg} / \mathrm{L}$. 蓝藻水华暴发期间, $\mathrm{TN}$ 浓度也有所上升, 均值为 $1.97 \mathrm{mg} / \mathrm{L}$, 最大升幅为 $18.7 \%$. 这主要与浮游植物的生物 量增加相关 ${ }^{[6]}$. 治理后, 冬季维持在较高浓度范围内 $(1.85-3.14 \mathrm{mg} / \mathrm{L})$, 均值为 $2.56 \mathrm{mg} / \mathrm{L}$, 较治理前冬季的 平均浓度上升 $77.8 \%$. 这主要是因为蓝藻水华暴发后, 大面积微囊藻死亡后, 分解释放出大量氮; 冬季浮游 植物生物量维持在相对低的水平, 且这时菹草的生长几乎完全或大部分靠其根吸收底泥中的 $\mathrm{NH}_{3}-\mathrm{N}^{[7]}$, 所 以水中 $\mathrm{TN}$ 浓度较高. 到 3.4 月份, 菹草快速生长, 使水中的 $\mathrm{TN}$ 浓度大幅下降, 5 月蕰草死亡后, 浮游植物大 量繁殖, $\mathrm{TN}$ 维持在相对较低的水平.

治理前, 湖中 TP 的浓度处于一个较平稳的状态, 在 $0.12-0.19 \mathrm{mg} / \mathrm{L}$ 之间 (图 $4 \mathrm{c}$ ). 在水华暴发期, 随着 温度和 $\mathrm{pH}$ 值的升高, 加快了底泥中磷的释放速度 ${ }^{[8-9]}$, 使水中 $\mathrm{TP}$ 浓度逐渐升高. 同样, 在蕰草快速生长时, 水中的 TP 浓度也相应下降. 2006 年 TP 浓度较 2005 年有所下降, 因此治理有效降低了湖水中 TP 的浓度.

$2004-2006$ 年, 冬季玄武湖的 Chl. a 都处于较低的水平 (图 4d). 在藻华期间达到极值, 治理后, 湖中 Chl. a 的浓度明显低于治理前同期 Chl. a 浓度, 它与湖水中浮游植物数量变化呈显著正相关, 相关系数是 0.741 , 治理效果比较明显.

\section{4 结论}

玄武湖蓝藻水华治理过程跟踪监测表明, 治理后, 玄武湖属于轻度一中度富营养化水平. 水体透明度大 

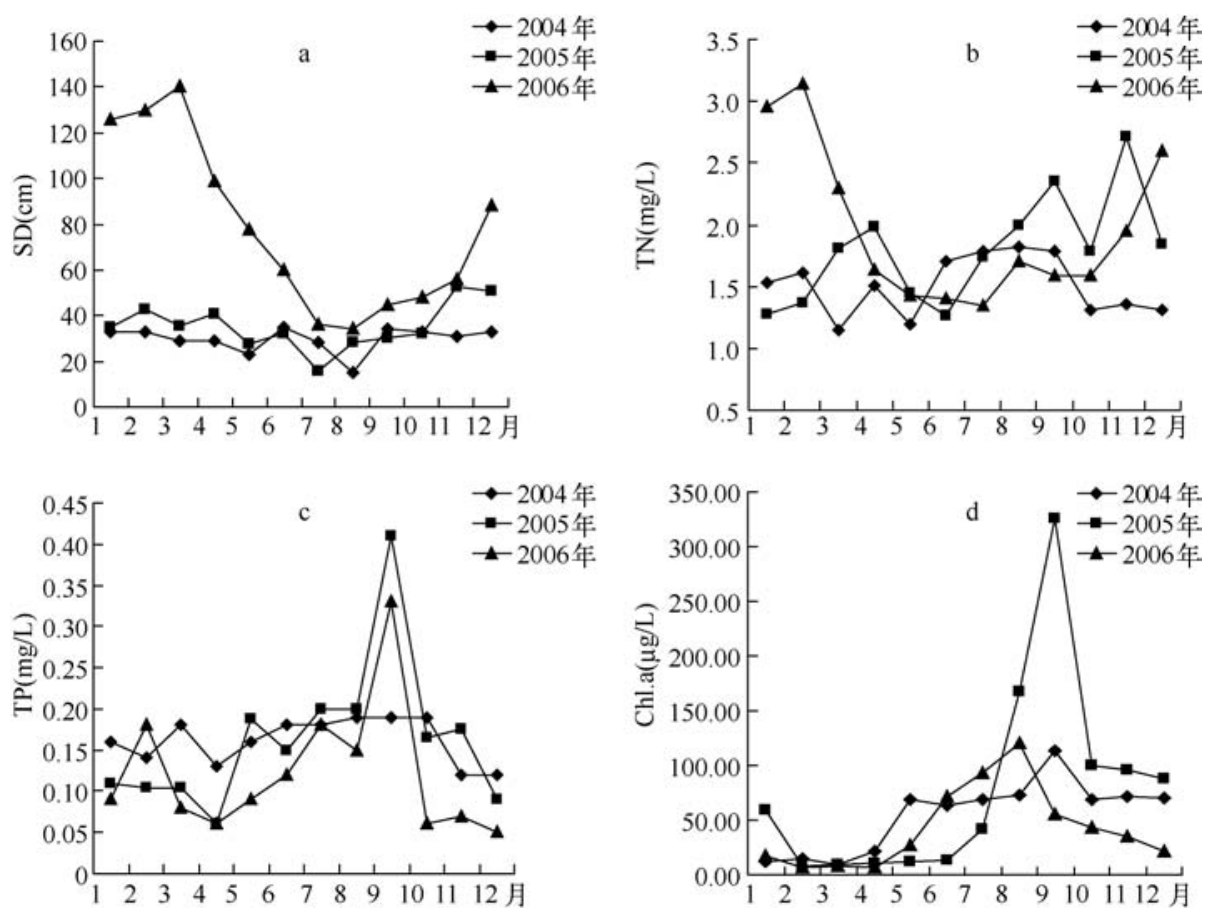

图 4 2004-2006 年 $\mathrm{SD}(\mathrm{a}) 、 \mathrm{TN}(\mathrm{b}) 、 \mathrm{TP}(\mathrm{c}) 、 \mathrm{Chl} . \mathrm{a}(\mathrm{d})$ 动态变化

Fig. 4 Dynamics of SD(a), TN(b), TP(c), Chl. a(d) during 2004-2006

为改善, 在冬季全湖清澈见底; 湖水中 TP 浓度主要来源于底质中磷的释放; 湖水中 TN 的浓度随浮游植物的 密度和菹草的生长而变动, 冬季较高, 春季较低; 浮游植物的密度下降, 种类数大幅增加. 应急治理后, 玄武 湖的水质和浮游植物群落结构都有一定程度改善.

近 10 余年来,玄武湖完成了环湖截污、清淤疏浚、生态补水等措施以控制水体富营养化、改善水质,在短期 内改善湖水水质、降低富营养化是困难的; 而城市湖泊的生态系统一旦退化就很难逆转,再恢复到健康的生态 系统需要付出较多的人力、财力和时间 ${ }^{[10]}$. 因此玄武湖富营养化治理亟待更多和更加有效的治理投人.

\section{5 参考文献}

[1 ] 梅卓华.玄武湖水域初级生产力和富营养化的调查研究. 江苏环境科技,1995,(3):7-10.

[2 ] 李永函,金送迪,刘国才. 蕰草型水体的理化因子和水生生物状况. 大连水产学院学报, 1992, 6(2): 1- 10.

[ 3 ] 金送笛,李永函,倪彩虹等. 蕰草 (Potamogeton crispus) 对水中氮、磷的吸收及若干影响因素. 生态学报, 1994, 14 (2) : 168-173.

[ 4 ] Colman JA, Santha CR. Critical concentrations of tissue nitrogen and phosphorus for growth rate and yield in the freshwater blue-green alga Microcystis aeruginosa Kütz. in the tropics. Aquatic Botany, 1988, 32 :167-177.

[ 5 ] Sas H. Lake restoration by reduction of nutrient loading: expectations, experiences, extrapolations. St. Augustin: Academic Verlag Richarz, Germany, 1989.

[6] 张哲海,梅卓华,孙洁梅等. 玄武湖蓝藻水华成因探讨. 环境监测管理与评价, 2006, 18(2):15-18.

[ 7 ] 王天阳,王国祥. 玄武湖菹草种群空间格局分析及其环境效应. 生态环境,2007, 16(6) : 1660-1664.

[8] 龚春生, 姚 琪, 范成新等. 城市浅水型湖泊底泥释磷的通量估算一以南京玄武湖为例. 湖泊科学, 2006,18 (2) : 179-183.

[ 9 ] 郭志勇, 李晓晨, 王 超等. $\mathrm{pH}$ 值对玄武湖沉积物中磷释放及形态分布的影响. 农业环境科学学报, 2007, 26(3): 873-877.

[10］彭俊杰, 李传红, 黄细花. 城市湖泊富营养化成因和特征. 生态科学, 2004, 23(4) :370-373. 